\title{
PERANCANGAN DESAIN BASIS DATA SISTEM INFORMASI GEOGRAFIS TANAH PENDUDUK DENGAN MENERAPKAN MODEL DATA RELASIONAL ( STUDI KASUS : DESA TUMBANG MANTUHE KABUPATEN GUNUNG MAS PROVINSI KALIMANTAN TENGAH )
}

Tri Amri Wijaya ${ }^{\text {a, } 1}$, Constantin Menteng ${ }^{\text {a,2 }}$, Adi Surya ${ }^{\text {a,3 }}$, Afis Julianto ${ }^{\text {a,4 }}$, Ema Utami ${ }^{\text {a,5 }}$

${ }^{a}$ Magister Teknik Informatika, Universitas Amikom Yogyakarta, Sleman Yogyakarta

${ }^{1}$ tri.1290@students.amikom.ac.id; ${ }^{2}$ constantin.1283@students.amikom.ac.id; ${ }^{3}$ adi.1291@ @students.amikom.ac.id;

4 afis.julianto@students.amikom.ac.id; 5 ema.u@amikom.ac.id

\section{ARTICLE INFO}

\section{Keywords}

Database Design

Database Management System

Relational Data

Data Base Life Cycle

Geographical Information

System

\section{ABSTRACT}

Database design is a data design process that is used to support the operational activities and goals of organizations and agencies. The use of databases on the geographic information system of residents' lands makes it possible to store, change, and display all data quickly and easily. One of the factors that become a problem in database design is the point of view of seeing data that varies between designers, programmers, and end-users. Therefore we need a methodology in good database design by applying procedures, techniques, tools, and documentation. The method used in this study used the Research and Development (R\&D) method, while the database design method used the Database Life Cycle (DBLC) method. The research variables were database design for the geographic information system of resident land with a relational data model. Research aspects include conceptual design, logical design, and physical design. The final result of this research is to produce 10 types of conceptual entities, produce a relationship diagram of the ten logical entities, and produce a physical design consisting of user_admin, user_pengguna, data_desa, data_kecamatan, data_kabupaten, jenis_tanah, data_penduduk, data_buku_c, data_mutasi, and data_sppt tables.

\section{Pendahuluan}

Teknologi informasi sangat berperan aktif dalam proses kelancaran aktifitas manusia sehari-hari. Teknologi informasi membuat sebagian orang meninggalkan informasi secara manual yang membutuhkan proses yang lebih lama. Penggunaan teknologi informasi yang tepat dapat membantu dalam mencari informasi dengan lebih cepat. Basis data atau database merupakan salah satu bagian penting dari penerapan teknologi informasi.

Basis data merupakan kumpulan beberapa data yang saling berelasi antara satu dengan yang lain sehingga data tersebut dapat dimanipulasi, ditampilkan dan dicari dengan cepat. Data merupakan fakta mengenai objek, orang dan lainnya yang dinyataka dengan nilai angka, karakter maupun simbol [1]. Selain berisi sebuah data, basis data juga berisi metadata [2]. Model basis data relasional merupakan suatu cara untuk merepresentasikan model data dalam perancangan basis data dimana model dari basis data relasional didasarkan pada record [3].

Proses perancangan basis data terdiri tiga tahapan yaitu perancangan konseptual, perancangan logikal dan perancangan fisikal. Perancangan konseptual adalah proses membangun model data yang digunakan dalam suatu perusahaan. Perancangan logikal adalah proses merancang model data yang digunakan dalam suatu perusahaan berdasarkan pada model data yang spesifik. Perancangan fisikal 
adalah proses menghasilkan deskripsi implementasi basis data pada penyimpanan sekunder, menggambarkan hubungan dasar dan organisasi file yang digunakan untuk mencapai akses yang efisien pada data [4].

Penelitian sebelumnya penah dilakukan oleh Abdulghani dan Ubaedilah (2018) menggunakan model waterfall, dimulai dari communication, planing, modeling, construction dan deployment untuk melakukan perancangan pada sistem informasi geografis sebaran tanah penduduk di Desa Tanjungsari Kabupaten Cianjur. Pada penelitian tersebut menggunakan Entity Relation Diagram (ERD) untuk memudahkan dalam logika perancangan basis data [5]. Penelitian lain yang dilakukan Sudarsono dan Muslim (2018) juga menggunakan metode perancangan System Development Life Cycle (SDLC) dengan menggunakan model waterfall pada sistem informasi geografis pemetaan blok tanah bersertifikat dan kepemilikan surat pemberitahuan pajak terutang di Desa Gunungsari Tasikmalaya. Perancangan basis data pada penelitian tersebut menggunkan model ERD untuk menjelaskan hubungan antar data dalam basis data [6]. Perancangan basis data dengan menggunakan DBLC pernah dilakukan oleh Nofiyani (2019) untuk mendukung sistem admnistrasi pelayanan dan perbaikan motor [7]. Menurut [8] DBLC sangat membantu dalam memberikan gambaran dari suatu sistem yang akan dibangun. Dengan menggunakan metode rancangan basis data ini juga memberikan manfaat dalam pengembang aplikasi dengan lebih baik dan benar [9].

Perancangan basis data pada sistem informasi akan memberikan sebuah visualisasi basis data yang dirancang menggunakan metode perancangan DBLC. Fokus pembahasan pada penelitian ini mengarah pada perancangan basis data relasional yang meliputi perancangan konseptual, perancangan logikal dan perancangan fisikal. Keberhasilan dalam membangun sebuah sistem informasi tidak terlepas dari sebuah konsep basis data yang baik. Hal inilah yang menjadi landasan utama perlunya sebuah rancangan basis sata dengan menggunakan model relasional.

\section{Metodologi Penelitian}

Pada penelitian ini menggunakan metode R\&D untuk membangun basis data. Menurut Sugiyono (2009) R\&D adalah metode yang digunakan untuk menghasilkan suatu produk tertentu dan menguji efektifitas dari produk tersebut [10]. Sebuah produk tidak selalu berbentuk benda maupun perangkat keras (Hardware), seperti alat tulis, buku dan alat pembelajaran lainnya. Akan tetapi, bisa dalam bentuk perangkat lunak (Software). Perancangan basis data menggunakan metode DBLC dengan variabel penelitian adalah perancangan basis data sistem informasi geografis tanah penduduk dengan model data relasional. Aspek penelitian meliputi perancangan basis data konseptual, perancangan basis data logikal dan perancangan basis data fisikal sesuai dengan Gambar 1.

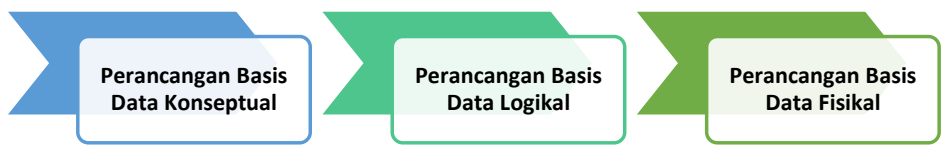

Gambar 1. Rancangan Basis Data

\section{Hasil dan Pembahasan}

Perancangan basis data merupakan bagian yang sangat penting dalam membangun sistem informasi. Pada saat perancangan basis data sering dihadapkan pada suatu masalah bagaimana sebuah basis data yang dibangun ini dapat memenuhi kebutuhan saat ini dan masa mendatang. Oleh sebab itu diperlukan perancangan basis data baik secara fisikal maupun secara konseptual. Pada perancangan konseptual akan menunjukkan sebuah entity dan relasi berdasarkan proses yang diinginkan oleh pengguna. Penentuan entity dan relasi dilakukan dengan mengambil data untuk dijadikan sebagai bahan analisis kebutuhan sistem informasi yang dibangun. Pada penelitian ini terdapat 3 tahapan yang digunakan untuk perancangan basis data, yaitu perancangan basis data konseptual, merancang basis data logikal dan merancang basis data fisikal. 


\subsection{Perancangan Basis Data Konseptual}

Proses membangun model data yang bersifat independent. Tahap ini dimulai dengan membuat model data konseptual dengan segala pertimbangan berdasarkan pada buku c di desa tersebut.

1. Identifikasi Tipe Entitas

Langkah awal menentukan identitas tipe-tipe entitas yang dibutuhkan terkait sistem basis data.

Tabel 1. Identifikasi Tipe Entitas

\begin{tabular}{|c|c|c|c|}
\hline No & Nama Entitas & Alias & Uraian \\
\hline 1 & Data Penduduk & data_penduduk & $\begin{array}{l}\text { Merupakan entitas yang berisikan informasi-informasi mengenai data } \\
\text { penduduk desa }\end{array}$ \\
\hline 2 & Data Buku C & data_buku_c & $\begin{array}{l}\text { Merupakan entitas yang berisikan informasi-informasi data tanah } \\
\text { penduduk desa }\end{array}$ \\
\hline 3 & Mutasi & data_mutasi & $\begin{array}{l}\text { Merupakan entitas yang berisikan informasi-informasi data mutasi } \\
\text { tanah }\end{array}$ \\
\hline 4 & SPPT & data_sppt & $\begin{array}{l}\text { Merupakan entitas yang berisikan informasi-informasi transaksi } \\
\text { pembayaran pajak tanah }\end{array}$ \\
\hline 5 & User Admin & user_admin & $\begin{array}{l}\text { Merupakan entitas yang mengelola dan mencatat data tanah penduduk } \\
\text { desa. }\end{array}$ \\
\hline 6 & User Pengguna & user_pengguna & Merupakan Entitas yang berisiskan data user penduduk \\
\hline 7 & Kabupaten & data_kabupaten & Merupakan Entitas yang berisikan informasi kabupaten \\
\hline 8 & Kecamatan & data_kecamatan & Merupakan Entitas yang berisikan informasi kecamatan \\
\hline 9 & Desa & data_desa & Merupakan Entitas yang berisikan informasi desa \\
\hline 10 & Jenis tanah & jenis_tanah & Merupakan Entitas yang berikan informasi jenis tanah \\
\hline
\end{tabular}

2. Identifikasi Hubungan Antar Entitas

Langkah selanjutnya melakukan identifikasi hubungan-hubungan antar entitas dengan diagram hubungan antar entitas.

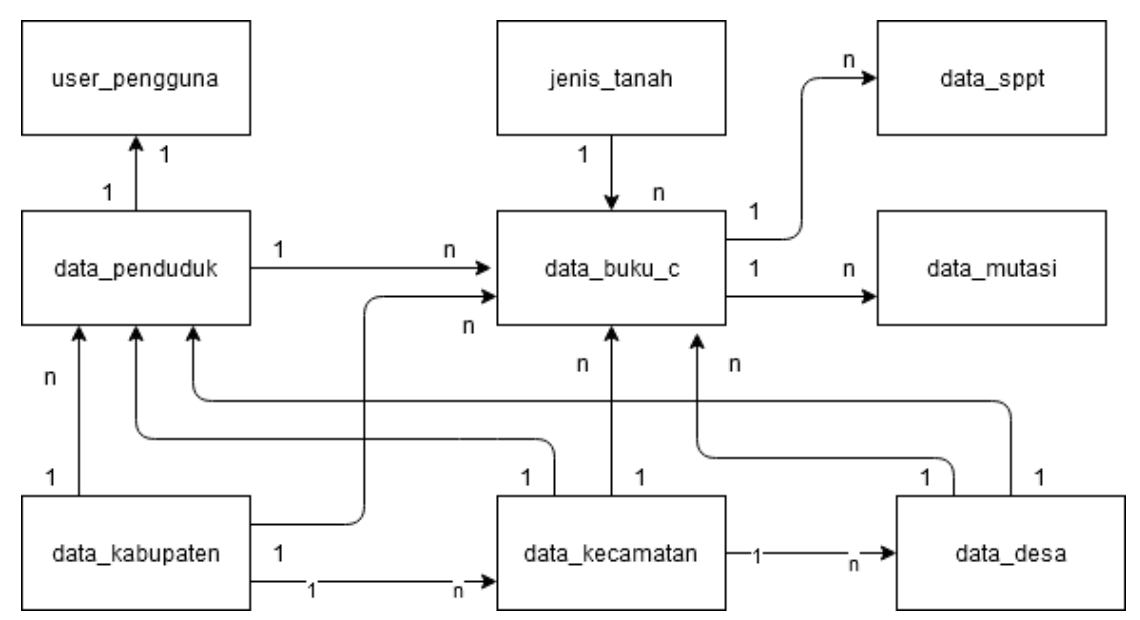

Gambar 2. Identifikasi Hubungan Antar Entitas

3. Membuat Entity Relationship Diagram (ERD) dengan Primary Key 


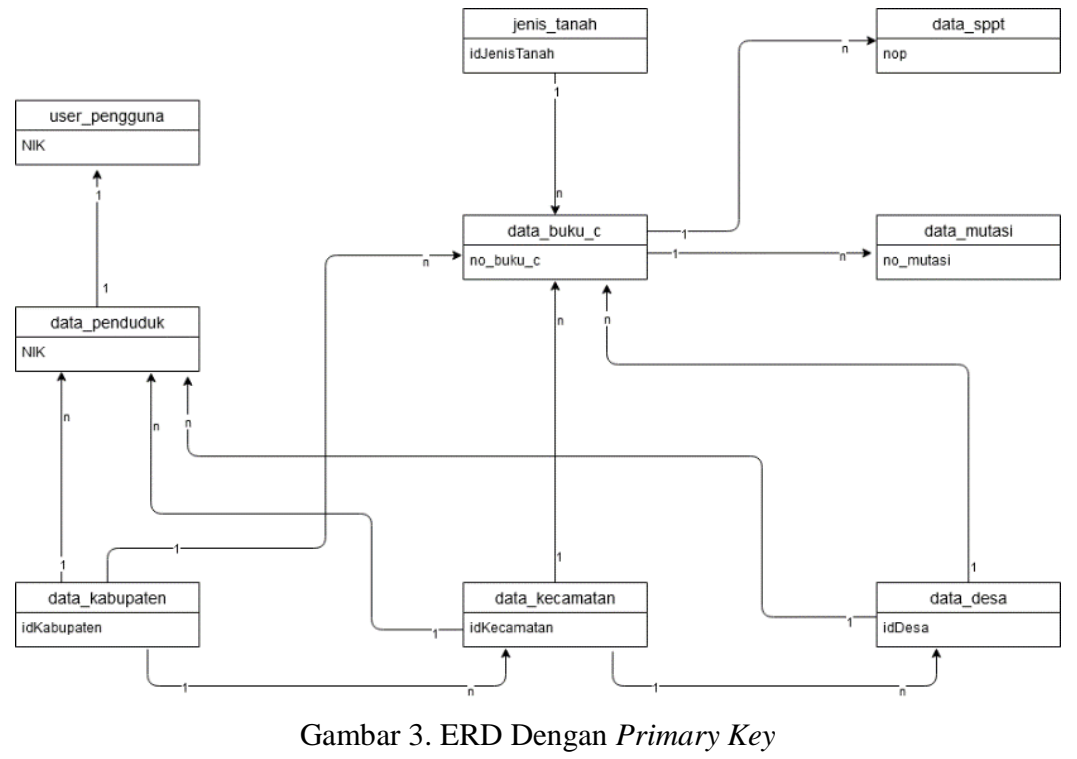

3.2. Perancangan Basis Data Logikal

1. Tipe Hubungan Binary One-to-Many (1..*)

Pada tipe ini entitas parent ke realisasi tabel yang mempresentasikan entitas child sebagai foreign key.

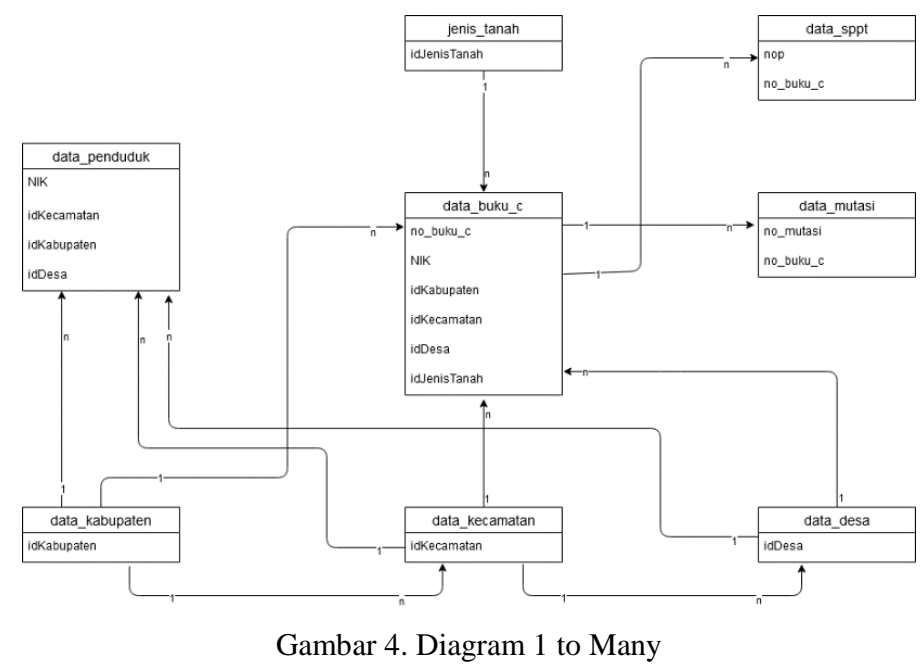

2. Tipe Hubungan Binary One-to-One (1..1)

Pada realisasi ini mempresentasikan sebuah hubungan 1...1, dengan mandatory satu entitas parent dan child.

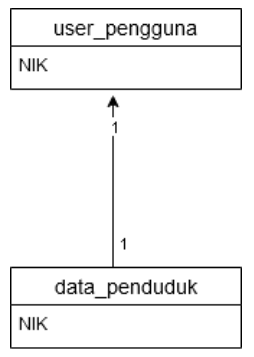

Gambar 5. Diagram 1 to 1

3. Entity Relationship Diagram (ERD) 


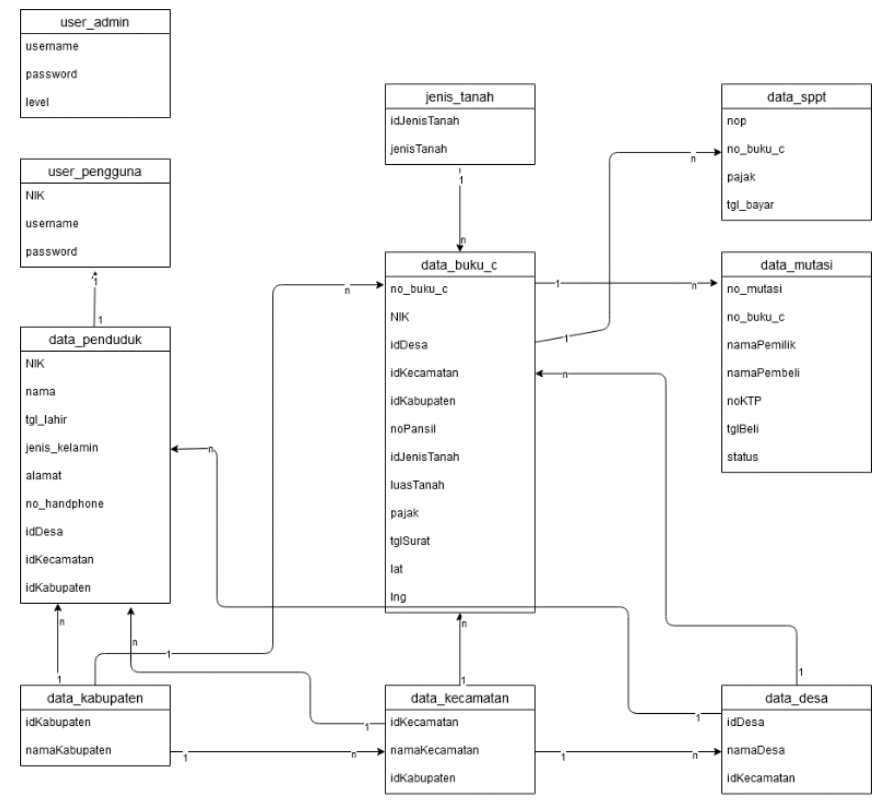

\subsection{Perancangan Basis Data Fisikal}

Gambar 6. ERD

Pada tahap ini untuk mengimplementasikan hasil desain basis data secara fisik pada media penyimpanan eksternal sesuai dengan ketentuan Database Management System (DBMS) yang digunakan. Salah satu DBMS yang digunakan dalam penelitian ini adalah My Structured Query Language (MySQL), berikut Tabel 2 sampai Tabel 11, hasil pembuatan 10 entitas sistem informasi geografis tanah penduduk.

Table 2. Tabel user_admin

\begin{tabular}{cllc}
\hline No & \multicolumn{1}{c}{ Nama Field } & Type & Size \\
\hline 1 & username $^{*}$ & Varchar & 30 \\
\hline 2 & Password & Varchar & 200 \\
\hline 3 & Level & Enum ('admin','operator') & - \\
\hline
\end{tabular}

Table 3. Tabel user_pengguna

\begin{tabular}{|c|c|c|c|}
\hline No & Nama Field & Type & Size \\
\hline 1 & NIK * & Varchar & 16 \\
\hline 2 & Username & Varchar & 30 \\
\hline 3 & Password & Varchar & 200 \\
\hline
\end{tabular}

Table 4. Tabel data_desa

\begin{tabular}{cllcc}
\hline No & Nama Field & Type & Size \\
\hline 1 & idDesa $*$ & Int & Int & 2 \\
\hline 2 & idKecamatan $* *$ & Varchar & 2 \\
\hline 3 & Desa & sa & 50 \\
\hline
\end{tabular}

Table 5. Tabel data_kecamatan

\begin{tabular}{cllcc}
\hline No & \multicolumn{1}{c}{ Nama Field } & Type & Size \\
\hline 1 & idKecamatan $*$ & Int & Int & 2 \\
\hline 2 & idKabupaten $* *$ & Varchar & 50 \\
\hline 3 & Kecamatan & & \\
\hline
\end{tabular}

Table 6. Tabel data_kabupaten

\begin{tabular}{clccc}
\hline No & Nama Field & Type & Size \\
\hline 1 & idKabupaten $*$ & Int & & 2 \\
\hline
\end{tabular}


Table 7. Tabel jenis_tanah

\begin{tabular}{cllcc}
\hline No & \multicolumn{1}{c}{ Nama Field } & Type & Size \\
\hline 1 & idJenisTanah * & Int & 2 \\
\hline 2 & jenisTanah & Varchar & 20 \\
\hline
\end{tabular}

Table 8. Tabel data_penduduk

\begin{tabular}{|c|c|c|c|}
\hline No & Nama Field & Type & Size \\
\hline 1 & NIK * & Varchar & 16 \\
\hline 2 & Nama & Varchar & 50 \\
\hline 3 & tglLahir & Date & 20 \\
\hline 4 & jenisKelamin & Enum ('L','P') & - \\
\hline 5 & Alamat & Varchar & 50 \\
\hline 6 & noHandphone & Varchar & 15 \\
\hline 7 & idDesa $* *$ & Int & 2 \\
\hline 8 & idKecamatan $* *$ & Int & 2 \\
\hline 9 & idKabupaten $* *$ & Int & 2 \\
\hline
\end{tabular}

Table 9. Tabel data_sppt

\begin{tabular}{cllcc}
\hline No & & & Type & Size \\
\hline 1 & nop $*$ & Varchar & & 20 \\
\hline 2 & noBukuC $* *$ & Varchar & 20 \\
\hline 3 & Pajak & Double & - \\
\hline 4 & tglPembayaran & Date & Type & - \\
\hline & & Table 10. Tabel data_buku_c & Size \\
\hline No & & & 20 \\
\hline 1 & Nama Field & Varchar & 16 \\
\hline 2 & NIK $* *$ & Varchar & 20 \\
\hline 3 & noParsil & Varchar & - \\
\hline 4 & luasTanah & Double & - \\
\hline 5 & Pajak & Double & - \\
\hline 6 & tglSurat & Date & 20 \\
\hline 7 & Lat & Varchar & 20 \\
\hline 8 & Lng & Varchar & 2 \\
\hline 9 & idJenisTanah $* *$ & Int & 2 \\
\hline 10 & idDesa $* *$ & Int & 2 \\
\hline 11 & idKecamatan $* *$ & Int & 2 \\
\hline 12 & idKabupaten $* *$ & Int & \\
\hline
\end{tabular}

Table 11. Tabel data_mutasi

\begin{tabular}{|c|c|c|c|}
\hline No & Nama Field & Type & Size \\
\hline 1 & noMutasi $*$ & Varchar & 20 \\
\hline 2 & noBukuC ** & Varchar & 20 \\
\hline 3 & namaPemilik & Varchar & 50 \\
\hline 4 & namaPembeli & Varchar & 50 \\
\hline 5 & noKTPPembeli & Varchar & 16 \\
\hline 6 & tglBeli & Date & - \\
\hline 7 & Status & Varchar & 10 \\
\hline
\end{tabular}

Tahap selanjutnya adalah menentukan relasi dasar yang sudah diidentifikasi, dipresentasikan kedalam Database Design language (DDL) untuk menentukan data variablenya. DDL merupakan kumpulan perintah SQL yang berfungsi untuk create (membuat), alter (merubah) dan drop (menghapus) struktur beserta tipe data pada objek basis data. Berikut ini perintah DDL yang diimplementasikan pada sistem informasi geografis tanah penduduk.

1. SQL CREATE TABLE user_admin 
CREATE TABLE user_admin ( username varchar(30) primary key, password varchar(200) NOT NULL, level enum('admin','operator') NOT NULL )

2. SQL CREATE TABLE user_pengguna

CREATE TABLE user_pengguna ( nik varchar(16) PRIMARY KEY, username varchar(30) NOT NULL, password varchar(200) NOT NULL )

3. SQL CREATE TABLE data_penduduk

CREATE TABLE data_penduduk (

Nik varchar(16) PRIMARY KEY,

nama varchar(50) NOT NULL,

tglLahir date NOT NULL,

jenisKelamin enum('L','P') NOT NULL,

alamat varchar(50) NOT NULL,

noHandphone varchar(15) NOT NULL,

idDesa int(2) NOT NULL,

idKecamatan int(2) NOT NULL,

idKabupaten int(2) NOT NULL,

FOREIGN KEY (idDesa) REFERENCES data_desa(idDesa) ON DELETE CASCADE ON UPDATE

CASCADE,

FOREIGN KEY (idKecamatan) REFERENCES data_kecamatan(idKecamatan) ON DELETE CASCADE ON UPDATE CASCADE,

FOREIGN KEY (idKabupaten) REFERENCES data kabupaten(idKabupaten) ON DELETE CASCADE ON UPDATE CASCADE )

4. SQL CREATE TABLE data_desa

CREATE TABLE data desa (

idDesa int(2) PRIMARY KEY AUTO_INCREMENT,

idKecamatan int(2) NOT NULL,

desa varchar(50) NOT NULL,

FOREIGN KEY (idKecamatan) REFERENCES data_kecamatan(idKecamatan) ON DELETE CASCADE ON UPDATE CASCADE )

5. SQL CREATE TABLE data_kecamatan

CREATE TABLE data_kecamatan (

idKecamatan int(2) PRIMARY KEY AUTO_INCREMENT

idKabupaten int(2) NOT NULL,

kecamatan varchar(50) NOT NULL,

FOREIGN KEY (idKabupaten) REFERENCES data_kabupaten(idKabupaten) ON DELETE CASCADE ON UPDATE CASCADE )

6. SQL CREATE TABLE data_kabupaten

CREATE TABLE data_kabupaten (

idKabupaten int(2) PRIMARY KEY AUTO_INCREMENT,

kabupaten varchar(50) NOT NULL )

7. SQL CREATE TABLE jenis_tanah

CREATE TABLE jenis tanah (

idJenisTanah int(2) PRIMARY KEY AUTO_INCREMENT,

jenisTanah varchar(20) NOT NULL )

8. SQL CREATE TABLE data_buku_c

CREATE TABLE data_buku_c (

noBukuC varchar(20) PRIMARY KEY,

nik varchar(16) NOT NULL,

noPersil varchar(20) NOT NULL,

luasTanah double NOT NULL,

pajak double NOT NULL,

tglSurat date NOT NULL,

lat varchar(20) NOT NULL,

Ing varchar(20) NOT NULL,

idJenisTanah int(2) NOT NULL,

idDesa int(2) NOT NULL,

idKecamatan int(2) NOT NULL, 
idKabupaten int(2) NOT NULL,

FOREIGN KEY (nik) REFERENCES data penduduk(nik) ON DELETE CASCADE ON UPDATE CASCADE, FOREIGN KEY (idJenisTanah) REFERENCES jenis_tanah(idJenisTanah) ON DELETE CASCADE ON UPDATE CASCADE,

FOREIGN KEY (idDesa) REFERENCES data desa(idDesa) ON DELETE CASCADE ON UPDATE CASCADE, FOREIGN KEY (idKecamatan) REFERENCES' data_kecamatan(idKecamatan) ON DELETE CASCADE ON UPDATE CASCADE,

FOREIGN KEY (idKabupaten) REFERENCES data_kabupaten(idKabupaten) ON DELETE CASCADE ON UPDATE CASCADE )

9. SQL CREATE TABLE data_sppt

CREATE TABLE data_sppt (

nop varchar(20) PRIMARY KEY,

noBukuC varchar(20) NOT NULL,

pajak double NOT NULL,

tglPembayaran date NOT NULL,

FOREIGN KEY (noBukuC) REFERENCES data_buku_c(noBukuC) ON DELETE CASCADE ON UPDATE CASCADE )

10. SQL CREATE TABLE data_mutasi

CREATE TABLE data mutasi (

noMutasi varchar(20) PRIMARY KEY,

noBukuC varchar(20) NOT NULL,

namaPemilik varchar(50) NOT NULL,

namaPembeli varchar(50) NOT NULL,

noKTPPembeli varchar(16) NOT NULL,

tglBeli date NOT NULL,

status varchar(10) NOT NULL,

FOREIGN KEY (noBukuC) REFERENCES data_buku_c(noBukuC) ON DELETE CASCADE ON UPDATE

CASCADE )

Hasil dari perancangan basis data ini, didapat 10 tabel yang dibuat menggunakan MySQL Server. Perancangan basis data menggunakan model data relasional khususnya basis data sistem informasi geografis tanah penduduk dimaksudkan agar setiap tabel pada basis data saling mempunyai keterkaitan demi menjamin integritas data. Diharapkan dengan penerapan model data relasional akan memberikan visualisasi yang jelas dan memberikan kemudahan bagi programer ketika ingin membangun aplikasi sistem informasi geografis tanah penduduk.

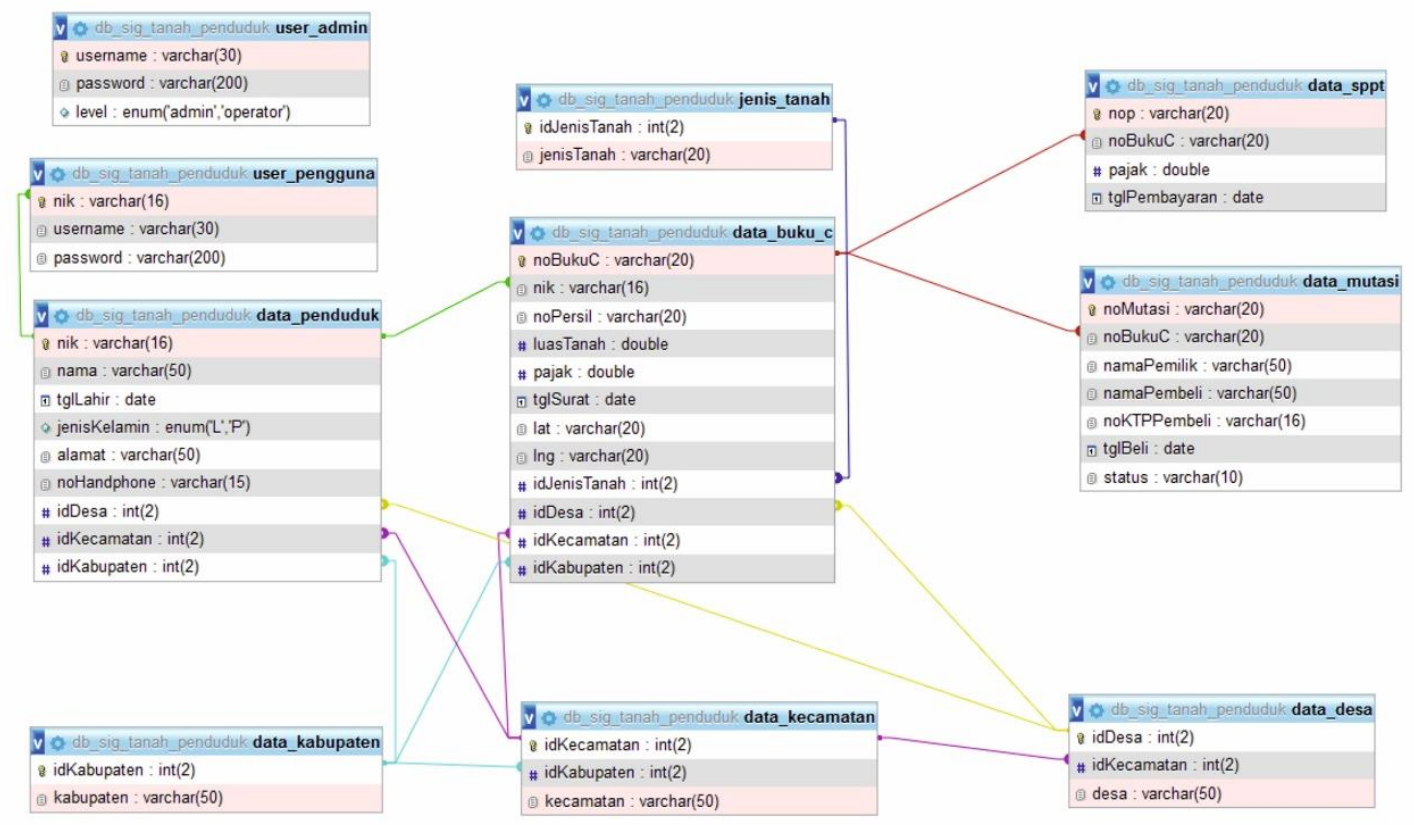

Gambar 6 : Relasional Diagram MySql 


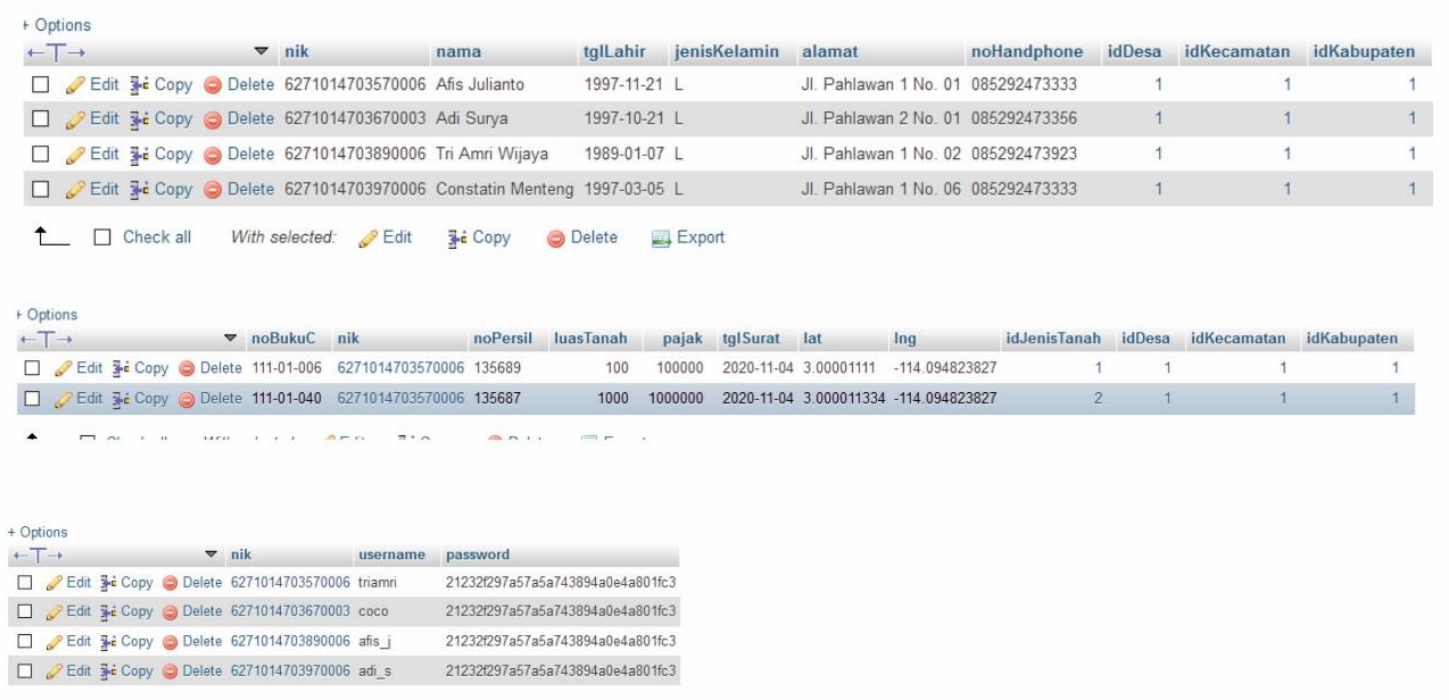

Gambar 7 : Hasil Data Inputan

\section{Kesimpulan}

Pada perancangan basis data dengan menggunakan metode DBLC ini dapat disimpulkan bahwa basis data ini memiliki entitas cukup sederhana dan membentuk basis data yang relasional dengan rincian sebagai berikut :

1. Mengunakan desain konseptual akan mempermudah dalam pembuatan entitas yang diperlukan.

2. Dengan model basis data logikal didapat 9 (sembilan) entitas yang memiliki hubungan relasional baik itu hubungan binary One-to-Many ataupun hubungan binary One-to-One.

3. Untuk membuat sebuah aplikasi yang baik tidak terlepas dari sebuah model basis data yang digunakan, maka perlu dibangun dengan model data relasional.

\section{Daftar Pustaka}

[1] Kusrini, "Strategi Perancangan dan Pengelolaan Basis Data", Yogyakarta : Andi, 2007.

[2] B. Raharjo, "Belajar Otodidak membuat Database Mengunakan MySQL", Bandung : Informatika, 2011.

[3] M. P. Putri, E. Apriadi and D. M. Asmoro, "Perancangan Basis Data Sistem Informasi Akademik SMK Swakarya Palembang," Teknomatika, vol. 09, no. 02, pp. 183-196, 2019.

[4] T. Connolly and C. Begg, "Database Systems: A practical Approach to Design, Implementation, And Management (Fifth Edition)", Boston : Pearson Education, 2010.

[5] T. Abdulghani and E. Ubaedilah, "Analisis Dan Perancangan Sistem Informasi Geografis Sebaran Tanah Penduduk (Studi Kasus Desa Tanjungasari, Kab. Cianjur)," J. Produktif, vol. 2, pp. 1-12, 2018.

[6] N. Sudarsono and A. A. Muslim, "Sistem Informasi Geografis Pemetaan Blok Tanah Bersertifikat Dan Kepemilikan Surat Pemberitahuan Pajak Terutang Di Desa Gunungsari Kecamatan Sukaratu Kabupaten Tasikmalaya," Semin. Nas. Multi Disiplin Ilmu, vol. 1, no. 1, pp. 887-893, 2017.

[7] Nofiyani, "Model Basis Data Untuk Mendukung Sistem Administrasi Pelayanan dan Perbaikan Motor," Simp. Nas. Ilm., no. November, pp. 367-375, 2019.

[8] Gat, "Perancangan Basis Data Perputakaan Sekolah dengan Menerapkan Model Data Relasional," Citec J., vol. 2, No. 4, no. 4, pp. 304-315, 2015. 
[9] W. S. Prasetya, "Perancangan Model Basis Data Relasional Dengan Metode Database Life Cycle," Pros. Semin. Nas. Inform. 2015, pp. 91-98, 2015.

[10] Sugiyono, "Metode Penelitian Pendidikan Pendekatan Kuantitatif, Kualitatif, dan R \& D", Jakarta : Alfabeta, 2009. 